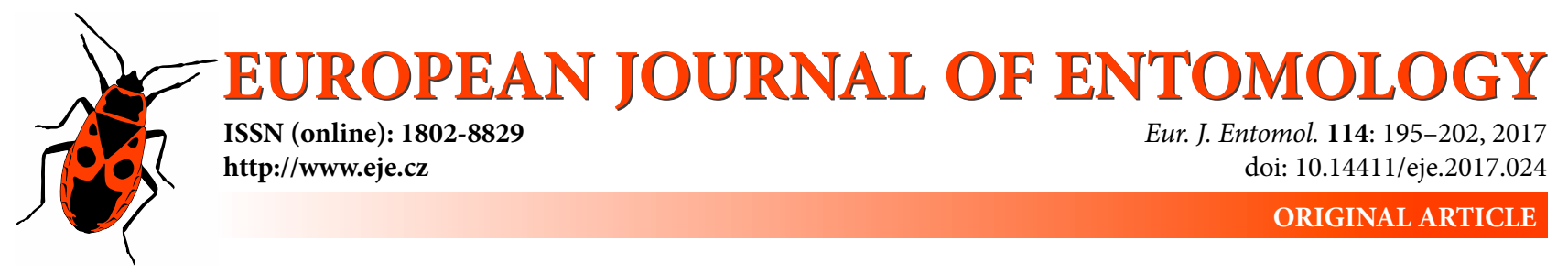

\title{
Expression of heat-shock protein genes in Apis mellifera meda (Hymenoptera: Apidae) after exposure to monoterpenoids and infestation by Varroa destructor mites (Acari: Varroidae)
}

\author{
NaJMeh SAHEBZADEH ${ }^{1}$ and WeI Hong LAU ${ }^{2}$ \\ ${ }^{1}$ Department of Plant Protection, Faculty of Agriculture, University of Zabol, Zabol, Iran; \\ e-mails: najmeh.sahebzadeh@gmail.com,n.sahebzadeh@uoz.ac.ir \\ ${ }^{2}$ Department of Plant Protection, Faculty of Agriculture, Universiti Putra Malaysia, Serdang, Malaysia; \\ e-mail: lauweih@upm.edu.my
}

Key words. Apidae, Apis mellifera meda, honey bee, gene expression, heat shock protein, stress, survival, Varroa destructor

\begin{abstract}
Heat shock proteins ( $h s p s$ ) protect proteins in eukaryotic cells from damage. Expression of $h s p s$ in insects subject to different environmental stimuli is poorly characterized. Here, levels of expression of the $h s p s$ genes ( $h s p 40, h s p 70$, and $h s p 90)$ were recorded in Apis mellifera Linnaeus (Hymenoptera: Apidae) workers after exposure to sublethal concentrations of thymol, eucalyptol, a-pinene, trans-anethole, diallyl disulfide and infestation with Varroa mites. Our results show a dose-dependent upregulation in the levels of all the hsps tested after the bees were treated with thymol, eucalyptol and a-pinene. Although these upregulated expressions were statistically significant for $h s p 70$ and $h s p 90$ when the bees were treated with thymol and eucalyptol, they were not significant when treated with a-pinene. In addition, significant down-regulated expressions of the $h s p$ genes were recorded in the diallyl disulfide treatment. The transcriptions of all the $h s p s$ tested were significantly down-regulated when pupae were infested with different numbers (0-5) of Varroa mites. Thus, it is likely that $h s p s$ can be used as biomarkers of survival when honey bees are under toxic and pathogenic stress, but this needs to be confirmed.
\end{abstract}

\section{INTRODUCTION}

The synthesis of most proteins in insects and other animals declines when they are exposed to external stressors like toxins, heat, cold and anoxia, although the levels of heat shock protein ( $h s p s$ ) increase, which bind aberrant proteins and aid in their refolding. Hsp function is associated with co-chaperones such as the J-domain protein and hsp40 (King \& MacRae, 2015). When cells are subject to biotic and abiotic stress they synthesize hsps that function as molecular chaperones. Under normal conditions, these molecules assist proteins during secretion, degradation, folding, intracellular localization, assembly, etc. (Zhao \& Jones, 2012). Hsps are classified based on their molecular weight in kilo daltons ( $\mathrm{kDa})$, such as $h s p 40, h s p 60, h s p 70$, hsp 90, hsp100 and small hsps (shsps). Hsp40 is characterized by a 70 amino acid domain (J domain) called DnaJ (Carmel et al., 2011). Hsp40 acts as hsp70's co-chaperone, stimulates $h s p 70$-ATPase activity, and delivers unfolded proteins to $h s p 70$. The other hsps like hsp60, hsp70 and $h s p 90$ fold the proteins in ATP-dependent way (Szabo et al., 1996; King \& MacRae, 2015).

The responses of $h s p$ genes in useful insects like honey bees under stress have not been investigated in great detail. There are at least 36 hsps genes in the honey bee genome
(Elsik et al., 2014). Greater knowledge of the changes in expression and transcription patterns of hsps and related proteins could provide greater insight and a better understanding of honey bee responses to stress at cellular and physiological levels.

A sudden large decline in the honeybee population (disappearing disease), which is called colony collapse disorder (CCD), has been attributed to pathogen infections or pesticide toxicity (Oldroyd, 2007). The mechanism of CCD is still unknown. Pesticides, pathogens (viruses and mites), environmental stimuli (heat, cold and others), genetic factors, changes in beekeeping practices, etc. probably induce CCD (Van Engelsdorp et al., 2009; Lu et al., 2014; Zaluski et al., 2015). Application of synthetic pesticides for managing agricultural pests or parasitic mites of honey bees (Varroa spp., Tropilaelaps clareae and Acarapis woodi) can themselves endanger the vitality of the colonies and are becoming increasingly problematic in apiaries. In addition, there may also be a residue of synthetic acaricides in honey bee products (Johnson et al., 2010; Singh, 2014; Locke, 2016). In the last few decades, bioactive effects of botanical insecticides have been touted as alternatives to synthetic insecticides because of their lower hazardous effects on human health and the environment (Isman, 2006). 
Because of the significant threat to honey bee health posed by Varroa mites, it is important that beekeepers monitor and control the levels of mites in their colonies. Recently, Varroa mites became resistant to synthetic insecticides as a result of their exclusive and consistent use. As a consequence, plant-derived compounds are being seriously considered for use as bio pesticides in Varroa management (Colin, 1990; Carayon et al., 2013; Xavier et al., 2015). These bio pesticides occur in plants belonging to certain plant families, such as Amaryllidaceae, Apiaceae, Asteraceae, Lamiaceae, Lauraceae, Myrtaceae, Piperaceae, Poaceae, Rutaceae, Zingiberaceae, etc. (Sahayaraj, 2014).

In this study, a carefully controlled and fully crossed laboratory experimental design was used to determine the effects of five monoterpeoids (thymol, eucalyptol, $\alpha$-pinene, diallyl disulfide and trans-anethole) and the mite Varroa on the level of expression of different hsp genes ( $h s p 40$; $h s p 70 ; h s p 90)$ in honey bee workers. Here, we attempt to answer the following questions: (1) Are there differences in the patterns of expression of the $h s p$ genes in honey bees exposed to monoterpenoids? (2) Are there differences in the expression of these hsp genes in honey bees infested with Varroa mites?

\section{MATERIALS AND METHODS}

\section{Chemicals}

The five monoterpenoids, thymol (99\%), eucalyptol (99\%), $\alpha$-pinene $(98 \%)$, diallyl disulfide $(80 \%)$ and trans-anethole $(99.5 \%)$, were obtained from Sigma-Aldrich (Spain).

\section{Collection of mites and insects}

Adults of Varroa destructor (Anderson \& Trueman) (Acari: Varroidae) and $A$. mellifera workers (10-15 days old) were collected from colonies of $A$. mellifera meda located at Zabol (Sistan va Baluchestan, Iran) during July to August 2015. These collections did not involve endangered or protected species of honey bees and no specific permissions were required since the responsible beekeeper granted access to his apiary. Adults were collected from frames without brood, anesthetized with carbon dioxide $\left(\mathrm{CO}_{2}\right)$, transferred to the laboratory and placed in plastic containers $\left(12 \times 12 \times 5 \mathrm{~cm}^{3}\right)$.

\section{Exposure of Varroa mites to monoterpenoides}

Colonies of $A$. mellifera that were heavily infested with Varroa mites and had not been treated with varroacides for six months were used as the source of Varroa mites. Varroa mites were removed from infested honey bee workers as described by Ariana et al. (2002). The infested adult honey bees ( 1000-1500) were shaken directly from bee frames into an apparatus composed of an outer and inner cylinder. $\mathrm{CO}_{2}$ was released into the inner cylinder for $5 \mathrm{~min}$ (flow rate of $5 \mathrm{~L} / \mathrm{min}$ ). After the bees were anesthetized, the apparatus was shaken several times to separate the mites from the adult honey bees. After the honeybees in inner cylinder recovered from the anesthesia they were returned to their mother colony. The mites were placed on white paper and approximately 200 Varroa mites were placed in each Petri dish (diameter $=60 \mathrm{~mm}$ ), with each dish constituting a replicate. Varroa mites in each dish were provided with five young bee pupae. Based on preliminary experiments, the lethal concentrations of four of the monoterpenoids, thymol, eucalyptol, $\alpha$-pinene and trans-anethole, were 1, 2, 5,12 , and $30 \mathrm{ppm}$, while concentrations of $0.5,1,1.5,2$, and 2.5 ppm were used to assay the lethal effects of diallyl disulfide on
Varroa mites. To determine the toxicity of the above monoterpenoids, $1 \mu \mathrm{L}$ of each concentration was poured on a piece of filter paper, which was attached to the inner surface of a Petri dish lid. Acetone was used as the solvent. After the solvent evaporated, the lids of Petri dishes were sealed tightly with Parafilm to avoid the volatilization of the monoterpenoids. The negative control consisted of a test group that was not exposed to the monoterpenoids. The positive control was treated only with acetone. All treatments and controls were incubated at $35 \pm 2{ }^{\circ} \mathrm{C}$ and $75 \pm 2 \%$ RH under a $12 \mathrm{~L}: 12 \mathrm{D}$ photoperiod. Five hours after the start of the treatments the numbers of dead Varroa mites were counted. The mites that did not move when touched with a fine soft brush were counted as dead. The toxicity experiments were done using a completely randomized design with three replicates.

\section{Exposure of honey bees to monoterpenoides}

Before commencing this experiment, honeybee adult workers were fed on a piece of cotton dental wick that was soaked with $20 \%$ sucrose solution. Bees were kept at $28 \pm 2^{\circ} \mathrm{C}$ and $58 \pm 5 \%$ relative humidity for three days.

Subsequently, the bees were exposed to monoterpenoids using a feeding method adapted from Koo et al. (2015). The lethal concentrations of the four monoterpenoids that caused $10-90 \%$ mortality of the Varroa mites were used to determine their side effects on honeybee adult workers. Prior to exposure, a series of concentrations of the monoterpenoids used in each treatment were individually dissolved in $20 \%$ sucrose solution and then poured into cotton wicks using a micropipette $(2 \mathrm{ml})$. This sucrose source was put in a plastic Petri dish $(50 \mathrm{~mm})$, placed at the bottom of a container and then bees $(n=5)$ were released into the container. Before exposure, the bees were placed in a refrigerator $\left(4^{\circ} \mathrm{C}\right)$ for approximately $10 \mathrm{~min}$ to immobilize them. For each monoterpenoid treatment, 5 groups of 5 bees (total 25 bees) were kept in the plastic containers. In the control only a solution of sucrose was used. The treatments and control were kept in an incubator $(24 \mathrm{~h}$ darkness; $28 \pm 2{ }^{\circ} \mathrm{C}$, and $58 \pm 5 \% \mathrm{RH}$ ) for five days. On the fifth day, the surviving bees were collected and the levels of expression of the $h s p 40, h s p 70$ and $h s p 90$ genes determined.

\section{Collection of honey bees infested with Varroa mite}

Honey bee pupae were collected from 10 colonies (Sistan region, Zabol, Iran) infested with Varroa mites. Brood cells were uncapped individually using fine forceps and after counting the number of adult and nymphal mites in the cells, bee pupae were collected from cells with $0,1,2,3,4,5$ mites. These pupae were kept at $-80^{\circ} \mathrm{C}$ until RNA extraction.

\section{Gene expression of $\boldsymbol{h s p s}$}

After five days of exposure, the abdomens of bees ( 5 samples per each concentration and experiment) were randomly selected and cryogenized in liquid nitrogen. TRIzol ${ }^{\circledR}$ reagent (Invitrogen, USA) was used to extract total RNA according to the manufacturer's instructions. The RNA was subsequently washed twice with $1 \mathrm{~mL} 75 \%$ ethanol, centrifuged at $12,000 \mathrm{~g}$ for $7 \mathrm{~min}$ and dried at room temperature. The RNA pellet was re-suspended in nuclease-free water $(20 \mu \mathrm{L})$. In addition, the RNA pellet was treated with DNase I (Invitrogen) to remove any contaminating genomic DNA. Immediately after extraction, RNA quantity and purity was evaluated using a spectrophotometer (Nanodrop2000c, Thermo Fisher Scientific). All samples had an excellent quality at $260 \mathrm{~nm}$ (200 ng RNA/sample). The RNAs were visualized on $1.5 \%$ agarose gel in TBE (pH 8.3).

With $1 \mu \mathrm{g}$ of extracted RNA for each treatment, complementary DNA (cDNA) was synthesized using a QuantiTect Reverse Transcription Kit (Qiagen). The synthesized cDNAs were adjusted to $50 \mu \mathrm{L}$ with sterile water and stored at $-80^{\circ} \mathrm{C}$ prior to further 
Table 1. Mean percent mortality of Varroa mites after exposure to different concentrations of four monoterpenoids (thymol, eucalyptol, a-pinene and trans-anethole) under laboratory conditions.

\begin{tabular}{|c|c|c|c|c|c|}
\hline \multirow{2}{*}{ Concentration (ppm) } & \multicolumn{5}{|c|}{ Varroa mite mortality (\%) after exposure to monoterpenoids } \\
\hline & thymol & eucalyptol & a-pinene & trans-anethole & diallyl disulfide \\
\hline $\begin{array}{l}\text { A } \\
\text { B } \\
\text { C } \\
\text { D } \\
\text { E } \\
\text { Control + } \\
\text { Control - }\end{array}$ & $\begin{array}{c}11.02 \pm 0.11 \mathrm{a} \\
18.41 \pm 0.16 \mathrm{~b} \\
40.25 \pm 1.81 \mathrm{c} \\
60.63 \pm 0.82 \mathrm{~d} \\
91.55 \pm 1.04 \mathrm{e} \\
0 \\
0\end{array}$ & $\begin{aligned} & 8.37 \pm 0.23 \mathrm{a} \\
& 16.09 \pm 1.42 \mathrm{~b} \\
& 31.61 \pm 1.79 \mathrm{c} \\
& 69.52 \pm 1.21 \mathrm{~d} \\
& 80.07 \pm 1.28 \mathrm{e} \\
& 0 \\
& 0\end{aligned}$ & $\begin{array}{r}8.11 \pm 0.17 \mathrm{a} \\
13.50 \pm 0.44 \mathrm{~b} \\
45.27 \pm 1.25 \mathrm{c} \\
59.19 \pm 1.21 \mathrm{~d} \\
73.08 \pm 1.09 \mathrm{e} \\
0 \\
0\end{array}$ & $\begin{array}{c}10.05 \pm 0.09 \mathrm{a} \\
15.32 \pm 0.27 \mathrm{~b} \\
39.45 \pm 0.87 \mathrm{c} \\
60.23 \pm 0.89 \mathrm{~d} \\
79.66 \pm 1.71 \mathrm{e} \\
0 \\
0\end{array}$ & $\begin{array}{c}10.31 \pm 1.10 \mathrm{a} \\
24.42 \pm 1.45 \mathrm{~b} \\
41.07 \pm 0.39 \mathrm{c} \\
79.01 \pm 0.44 \mathrm{~d} \\
93.25 \pm 1.07 \mathrm{e} \\
0 \\
0\end{array}$ \\
\hline
\end{tabular}

Means $( \pm$ SE) with different letters within each column differ significantly ( $p>0.05$; LSD tests). Experiments were replicated three times.

analysis. To perform Real-time PCR (RT-PCR), each reaction was prepared with a cDNA sample $(50 \mathrm{ng})$ for each treatment as a template, $10 \mathrm{pM}$ of gene-specific primers (Koo et al., 2015), SYBR green master mix (Invitrogen) and nuclease free water to a final volume of $25 \mu \mathrm{L}$. For the first PCR cycle, the reaction mixture was initially denatured at $95^{\circ} \mathrm{C}$ for $10 \mathrm{~min}$ ( 1 cycle), followed $15 \mathrm{~s}$ at $95^{\circ} \mathrm{C}$ for denaturing, $1 \mathrm{~min}$ for annealing at $60^{\circ} \mathrm{C}$, and was extend at $72^{\circ} \mathrm{C}(35 \mathrm{~s})$ for a total of 40 cycles. Fluorescence was measured during the annealing step. A dissociation step $\left(95^{\circ} \mathrm{C}\right.$ for $15 \mathrm{~s}, 60^{\circ} \mathrm{C}$ for $30 \mathrm{~s}, 95^{\circ} \mathrm{C}$ for $15 \mathrm{~s}$ ) was conducted to validate the amplification of a single product in each PCR reaction. To obtain cDNAs of the pupae infested with mites, samples were washed three times with sterile deionized water and dried on filter paper. Individual pupae ( 5 samples per treatment, 3 replications) were randomly selected and homogenized in a $1.5 \mathrm{ml}$ tube. Then the homogenate was treated with extract RNA. Synthesis cDNA and RT-PCR were conducted based on a procedure previously described by Koo et al. (2015). Actin was used as a reference gene to normalize the target genes (Lourenco et al., 2008). To obtain the relative quantities of $h s p$ genes, threshold cycle (ct) values were used. Data were analyzed using the $2^{-\Delta \Delta \mathrm{ct}}$ method $\left(2^{-\Delta \Delta \mathrm{ct}}=\right.$

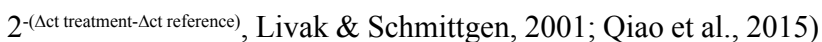
using IQ5 Optical system software (Bio-Rad). In the negative control, no cDNA template was used. We replicated the reactions three times. Significant differences among the gene expression levels of the treatments were analyzed using SPSS 16.0 software (Chicago, IL). In addition, one-way analysis of variance was used to compare the mean values $(p>0.05)$.

\section{RESULTS}

Varroa mites were killed by all of the five monoterpenoids tested under laboratory conditions (Table 1). The mortalities recorded were greater than $90 \%$ when the highest concentrations ( 30 and $2.5 \mathrm{ppm}$, respectively) of diallyl disulfide and thymol were used. As expected, all of the honey bee workers exposed to concentrations of monoterpenoids that were lethal for Varroa mites survived.

The levels of $h s p 40, h s p 70$, and $h s p 90$ mRNA in the honey bee workers and pupae responded to the different concentrations of monoterpenoids (Table 2). The results re-

Table 2. Relative level of mRNA expression of each $h s p$ in honey bee workers previously exposed to each of the 5 monoterpenoids tested.

\begin{tabular}{|c|c|c|c|c|}
\hline Monoterpenoid & Concentration (ppm) & hsp40 & hsp70 & hsp90 \\
\hline Thymol & $\begin{array}{c}0 \\
1 \\
2 \\
5 \\
12 \\
30\end{array}$ & $\begin{array}{l}3.09 \pm 1.07 \mathrm{~b} \\
3.12 \pm 1.11 \mathrm{~b} \\
3.20 \pm 0.77 \mathrm{~b} \\
3.41 \pm 0.16 \mathrm{~b} \\
3.60 \pm 1.03 \mathrm{~b} \\
4.51 \pm 0.55 \mathrm{ab}\end{array}$ & $\begin{array}{l}3.46 \pm 1.04 d \\
3.00 \pm 0.98 d \\
4.25 \pm 1.07 c \\
4.81 \pm 0.20 c \\
5.32 \pm 0.54 b \\
6.01 \pm 0.41 a\end{array}$ & $\begin{array}{l}2.50 \pm 0.11 \mathrm{e} \\
3.09 \pm 0.77 \mathrm{de} \\
3.82 \pm 1.91 \mathrm{~d} \\
4.44 \pm 0.09 \mathrm{c} \\
5.03 \pm 1.07 \mathrm{~b} \\
6.95 \pm 0.60 \mathrm{a}\end{array}$ \\
\hline Eucalyptol & $\begin{array}{c}0 \\
1 \\
2 \\
5 \\
12 \\
30 \\
\end{array}$ & $\begin{array}{l}3.08 \pm 0.32 a \\
3.11 \pm 0.75 a \\
3.32 \pm 0.21 a \\
3.41 \pm 1.42 a \\
3.44 \pm 0.89 a \\
3.78 \pm 0.75 a\end{array}$ & $\begin{array}{l}2.94 \pm 1.02 d \\
3.36 \pm 0.96 c \\
3.03 \pm 0.07 c \\
4.15 \pm 1.32 b \\
4.79 \pm 0.96 b \\
5.19 \pm 0.53 a \\
\end{array}$ & $\begin{array}{l}2.10 \pm 1.33 \mathrm{e} \\
2.55 \pm 0.55 \mathrm{e} \\
3.47 \pm 0.84 \mathrm{~d} \\
4.01 \pm 0.82 \mathrm{c} \\
5.10 \pm 0.11 \mathrm{~b} \\
6.51 \pm 0.82 \mathrm{a}\end{array}$ \\
\hline$\alpha$-pinene & $\begin{array}{c}0 \\
1 \\
2 \\
5 \\
12 \\
30 \\
\end{array}$ & $\begin{array}{l}3.01 \pm 0.33 \mathrm{a} \\
3.24 \pm 1.04 \mathrm{a} \\
3.60 \pm 0.99 \mathrm{a} \\
3.88 \pm 1.01 \mathrm{a} \\
4.05 \pm 0.56 \mathrm{a} \\
4.76 \pm 0.05 \mathrm{a} \\
\end{array}$ & $\begin{array}{l}3.62 \pm 0.71 \mathrm{a} \\
3.68 \pm 0.87 \mathrm{a} \\
3.70 \pm 0.07 \mathrm{a} \\
3.85 \pm 0.57 \mathrm{a} \\
4.90 \pm 0.61 \mathrm{a} \\
4.99 \pm 0.35 \mathrm{a} \\
\end{array}$ & $\begin{array}{l}5.11 \pm 1.03 a \\
5.29 \pm 0.85 a \\
5.56 \pm 1.03 a \\
5.73 \pm 0.22 a \\
5.81 \pm 1.04 a \\
6.00 \pm 0.22 a \\
\end{array}$ \\
\hline Trans anethole & $\begin{array}{c}0 \\
1 \\
2 \\
5 \\
12 \\
30 \\
\end{array}$ & $\begin{array}{l}4.53 \pm 0.27 \mathrm{a} \\
4.09 \pm 0.71 \mathrm{a} \\
4.00 \pm 0.44 \mathrm{a} \\
3.72 \pm 0.21 \mathrm{a} \\
3.54 \pm 0.87 \mathrm{a} \\
3.00 \pm 0.57 \mathrm{a}\end{array}$ & $\begin{array}{l}4.58 \pm 0.13 \mathrm{a} \\
4.00 \pm 0.41 \mathrm{a} \\
4.00 \pm 0.52 \mathrm{a} \\
3.57 \pm 0.32 \mathrm{a} \\
3.30 \pm 1.01 \mathrm{a} \\
3.33 \pm 0.52 \mathrm{a}\end{array}$ & $\begin{array}{l}6.49 \pm 0.55 a \\
6.37 \pm 0.18 \mathrm{a} \\
6.14 \pm 0.52 \mathrm{a} \\
6.11 \pm 0.07 \mathrm{a} \\
5.45 \pm 0.88 \mathrm{a} \\
5.10 \pm 1.07 \mathrm{a} \\
\end{array}$ \\
\hline Dially disulfide & $\begin{array}{c}0 \\
0.5 \\
1 \\
1.5 \\
2 \\
2.5\end{array}$ & $\begin{array}{l}5.40 \pm 0.38 \mathrm{a} \\
4.04 \pm 0.04 \mathrm{~b} \\
3.61 \pm 0.11 \mathrm{c} \\
2.75 \pm 0.28 \mathrm{~d} \\
2.34 \pm 1.87 \mathrm{~d} \\
2.03 \pm 0.05 \mathrm{~d}\end{array}$ & $\begin{array}{l}5.18 \pm 0.55 a \\
5.00 \pm 1.01 a \\
4.01 \pm 0.35 b \\
3.57 \pm 0.91 b \\
3.00 \pm 0.01 c \\
2.00 \pm 0.03 d\end{array}$ & $\begin{array}{l}6.55 \pm 0.12 a \\
6.50 \pm 0.09 a \\
5.70 \pm 0.71 b \\
5.54 \pm 0.37 b \\
5.01 \pm 0.70 c \\
5.00 \pm 0.58 c\end{array}$ \\
\hline
\end{tabular}

Relative levels of each $h s p$ were measured by real-time polymerase chain reaction (RT-PCR) with the actin gene serving as a reference (control) to normalize data. The different letters indicate statistically significant differences between treatments. Values are presented as mean $\pm \operatorname{SE}(n=5$, replication $=3)$. 


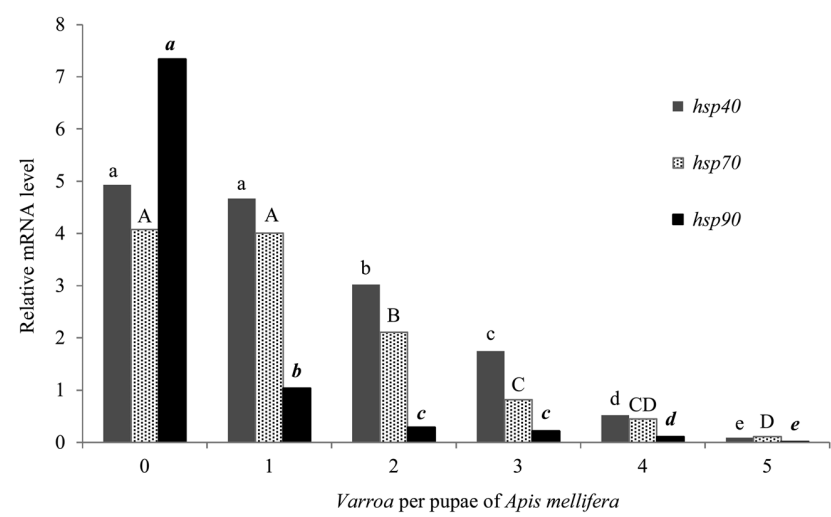

Fig. 1. Relative mRNA expression levels of $h s p s$ when honeybee pupae were exposure to Varroa mites. Relative levels of each $h s p$ were measured by real-time polymerase chain reaction (RT-PCR) with the actin gene serving as a reference (control) to normalise data. The different letters above each bar indicate statistical difference analyzed using SPSS 16.0 software (Chicago, IL) followed by Duncan's multiple comparison test $(p<0.05)$. Values are presented as mean $\pm \operatorname{SE}(n=5$, replication $=3)$.

veal a dose dependent up-regulation in the levels of $h s p 70$ and $h s p 90$ when the bee workers were exposed to thymol, eucalyptol and $\alpha$-pinene. Although these up-regulated expressions were statistically significant for $h s p 70$ and $h s p 90$ when the bees were treated with thymol and eucalyptol, the level of expression of $h s p 40$ was not significantly increased when the bees were exposed to any of the monoterpenoids tested. In addition, no significant up-regulations in the expression of $h s p 70$ and $h s p 90$ genes were induced by $\alpha$-pinene.

We also studied the expression levels of $h s p$ genes after exposure to trans-anethole and diallyl disulfide. Significant down-regulated expressions of the three genes tested were recorded in the bee workers treated with diallyl disulfide. Similarly, slightly down-regulated expressions of hsps were recorded in bees exposed to trans-anethole, but these changes were not significant (Table 2).

The transcripts of all the hsps tested were significantly down-regulated when bee pupae were exposed to different numbers of Varroa mites (Fig. 1).

\section{DISCUSSION}

As a group of highly conserved molecules, hsps, are involved in insect cell differentiation, cell cycle regulation and embryonic development. In addition, hsps are synthesized in response to different stressors indicating they have an important role in the physiology and biology of stressed cells (Stephanou \& Latchman, 2011). In general, hsps protect organisms from various stressors such as heat, toxins and pathogens. Recently, studies on insect responses to external stressors demonstrate that such stimuli induce highly significant changes in the expression profiles of hsps. Ritossa (1962) and Tissieres et al. (1974) were the first to study hsps in Drosophila melanogaster. Since then, hsps have been investigated in a number of insects, including Tribolium castaneum (Mahroof et al., 2005), Lucilia sericata (Tachibana et al., 2005), Spodoptera exigua (Jiang et al., 2012), Liriomyza sativa (Huang et al., 2009), Chilo suppressalis (Cui et al., 2010), Helicoverpa zea (Zhang \& Denlinger, 2010), Bombyx mori (Li et al., 2012; Gong et al., 2014), Frankliniella occidentalis (Wang et al., 2014), Lissorhoptrus oryzophilus (Yuan et al., 2014), Agrotis cnigrum (Wang et al., 2015), Sitophilus zeamais (Tungjitwitayakul et al., 2015), Apis mellifera (Koo et al., 2015), Plutella xylostella (Zhang et al., 2015) and their expressions in different insects reviewed (Shakya et al., 2012; Zhao \& Jones, 2012; Doganlar \& Doganlar, 2015).

Honey bees come in contact with various pollutants during foraging and as a consequence of controlling Varroa mites in apiaries. It is hypothesized that sub lethal concentrations of pesticides in the field can reduce the fecundity of honey bee pests as well as protecting foraging honey bees against pests. However, it is emphasized that sub lethal doses of pesticides disturb the physiology and behaviour of honey bees (Dai et al., 2010; Smodis Skerl \& Gregorc, 2010; Gregorc \& Ellis, 2011). As a result, the contamination of honey bee colonies with either miticides or pesticides could affect their physiology and any changes in the physiological parameters may result in the colony collapse disorder. Synthetic miticides or pesticides also affect the expression of hsps in honey bees. Lethal concentrations of pesticides like imidacloprid $(0.5-50 \mathrm{ppm})$ decrease the levels of $h s p s$ ( $h s p 70, h s p 90$, and grp 78) in honey bees (Koo et al., 2015). Despite their biological efficiency and the widespread application of botanical pesticides such as essential oils, their effects as stressors on expression profiles of hsps in insects have not yet been documented.

Untreated honey bee colonies infested with Varroa mites only survive for one to two years. Recent reports that Varroa mites have developed resistance to synthetic miticides have resulted in more attention being paid to developing botanical toxins for controlling mites in apiaries. The development of novel miticidal compounds is essential in order to combat the increasing resistance of mites to conventional miticides. Hence, in the search for alternative miticides the miticidal activity of plant secondary metabolites has been evaluated (Colin, 1990; Greatti \& Barbatinin, 1996; Ariana et al., 2002; Umpiérrez et al., 2011; Carayon et al., 2013; Singh, 2014; Li et al., 2017). It is well documented that plant essential oils can be used as fumigant miticides in the treatment of Varroa mites of which the monoterpenoids are probably the best-known (Carayon et al., 2013). The results mainly confirm that all five monoterpenoids in a vapor-phase toxicity bioassay can kill Varroa mites but not honey bees. Previous studies also show that plant essential oils, including camphor, eucalyptol, menthol and thymol, are effective against Varroa at concentrations of up to $50 \mathrm{mg} \cdot \mathrm{kg}^{-1}$ and safe for honey bees (Imdorf et al., 1999). The possibility of using essential oils in honey bee colonies with no resultant contamination of colony products, has encouraged researchers to investigate the physiological, behavioural, and biochemical effects and properties of essential oils with proven miticidal activity.

In spite of the evidence that honey bees exposed to pesticides and infestation with Varroa mites express immune genes (Boncristiani et al., 2012), no study has investigated 
the effects of secondary metabolites and Varroa on the transcript levels of hsps in honey bees. It was hypothesized that these stimuli are associated with changes in $h s p$ levels in treated and untreated samples. Our result demonstrate that the relative mRNA levels of the hsps tested in honey bees exposed to secondary metabolites and infestation with Varroa mites were changed either up or down in a way specific to each treatment. The levels of the hsps tested ( $h s p 40$, $h s p 70$, and $h s p 90)$ gradually increased when the concentrations of thymol eucalyptol and $\alpha$-pinene were increased (Table 2). This increase indicates that the chaperone actions of hsps are involved in ameliorating the toxicity of these monoterpenoids. Up-regulation of hsps promotes tolerance in stressed cells (Du Rand et al., 2015). Our results confirm that sub lethal concentrations of thymol and eucalyptol induce an increase in the levels of hsps in honey bees.

Different thymol-based formulations can be used to effectively control Varroa mites (Umpiérrez et al., 2011). A thymol-based varroacide significantly alter the level of gene expression, metabolic responses including immunity, detoxification and development in honey bees (Boncristiani et al., 2012). Researchers report significant changes in the level of expression of different $h s p$ genes in different organisms in response to plant secondary metabolites. For example, Burt et al. (2007) show that Escherichia coli treated with carvacrol $(1 \mathrm{Mm})$ produce a significant amount of $h s p 60$. Like thymol, carvacrol is a phenol, which inhibits the function of transient receptor potential-like channels in insects (Parnas et al., 2009).

Eucalyptol (also known as 1,8-cineole) is another monoterpenoid, which potentially could be used to control Varroa mites (Imdorf et al., 1996; Melathopoulos \& Gates, 2003). The efficiency of monoterpenoids, including camphor, menthol, linalyl acetate etc., against $V$. destructor has been assessed and several of them are toxic (GonzalezColoma et al., 2010; Umpiérrez et al., 2011; Singh, 2014).

In this study, the level of $h s p$ gene expression induced by $\alpha$-pinene is dose-dependent. This monoterpenoid produced no significant increase in the level of heat shock proteins $(p>0.05)$. The levels of hsps in honey bees treated with trans-anethole were down-regulated, but insignificantly so. Hummelbrunner \& Isman (2001) show that for Spodoptera litura (F.) larvae trans-anethole synergizes the toxicity of thymol. Therefore, it is likely that such compounds are stressors for honey bees and if combined their toxicity is increased synergistically. It is assumed that the mechanism of toxicity of such monoterpenoids is the same or the target sites in insects are similar, but the level of understanding is poor. In an attempt to characterize the detoxification mechanisms in stressed honey bees, Du Rand et al. (2015) report that active detoxification of nicotine by $A$. mellifera scutellata is associated with metabolic and proteomic responses such as up-regulation of heat shock proteins.

Sun et al. (2014) studied the level of expression of $h s p 90$ in Apolygus lucorum (Heteroptera: Miridae) in response to different stressors such as pesticides, including cyhalothrin, imidacloprid, chlorpyrifos and emamectin benzoate.
Their results confirm that after pesticide treatment using $\mathrm{LD}_{50} \mathrm{~s}$, the mRNA levels of AlHSP90 in surviving male and female adults are significantly higher than in the controls. Transcriptional results confirm that AlHSP90 is an important gene involved in the resistance to pesticides.

In this study, the potential for using diallyl disulfide for controlling Varroa mites is emphasized. This compound and diallyl trisulfide are the main components of garlic essential oil and are both insecticidal and bactericidal (Yang et al., 2009). The application of a mixed formulation of garlic with "sulfur and pepper" (Greatti \& Barbatinin, 1996) and "neem, garlic, and tobacco extracts" (Qayyoum et al., 2013) have proved effective in managing Varroa mites. Despite the fact that garlic and its components (diallyl disulfide, diallyl trisulfide) are toxic for Varroa, the metabolic responses of honey bees to these substances have not been investigated. Our results indicate that the levels of the hsps tested decrease when the concentration of diallyl disulfide is increased. This indicates that it may not be possible to use changes in the chaperone action of hsps in honey bees as biosensors of particular environmental stresses such as pesticide or botanicals (Feder \& Hofmann, 1999). In addition, expression of the mRNA levels of hsps indicates that these genes are affected by the toxicity of this compound. Highly down regulated $h s p s$ in honey bees in response to diallyl disulfide indicate that these proteins cannot prevent cell injury in honey bees. Therefore, its use for controlling Varroa mites is dependent on determining whether honey bees can tolerate this compound.

Our results demonstrate that an infestation of Varroa mites can result in significantly lower transcript levels of all the hsps tested in honey bees. There was a significant decrease in level of these genes in bees infested with 1 to 5 mites. There was a significant down-regulation in the mRNA level of $h s p 90$ in bees infested with one mite compared to the control. Our results show that the number of mites regularly infesting bee workers probably decrease the immune responses of bees, which need to be investigated in future studies. Zhu et al. (2013) investigate the roles of $h s p s$ ( $h s p 20, h s p 75$ and $h s p 90$ ) in the host-parasite interaction between Pieris rapae (Lepidoptera: Pieridae) and its parasitoid Pteromalus puparum (Hymenoptera: Pteromalidae). Their results indicate that in parasitized pupae, the hsp 20 transcripts in response to P. puparum are significantly higher than in the controls. In addition, the expression of $h s p 75$ and $h s p 90$ were down-regulated in parasitized pupae. They conclude that the hsps tested are involved in host-parasitoid interactions and the transcription of $h s p$ could be a component of the syndrome of parasitized hosts (Zhu et al., 2013). Rinehart et al. (2002) and Shim et al. (2007) report similar interactions in Sarcophaga crassipalpis (Diptera: Sarcophagidae) parasitized by $\mathrm{Na}$ sonia vitripennis (Hymenoptera: Pteromalidae) and Plodia interpunctellaI (Lepidoptera: Pyralidae) parasitized by Bracon hebetor (Hymenoptera: Braconidae), respectively. In general, the expression of these $h s p$ genes in response to parasitization indicates they have an important role in hostparasite interactions. Zhu et al. (2013) suggest that during 
immune defense, the production of reactive oxygen species (ROS) is often induced, which results in proteotoxicity of host cells, death of the parasitoid and protein denaturation. In addition, $h s p s$ as cytoprotective proteins are activated in response to an increase in ROS levels or toxic substances produced by pathogens. The regulation of the expression of $h s p$ in an insect after parasitization could protect the host's tissues and the developing parasitoid from noxious agents produced by the host's immune response (Zhu et al., 2013).

\section{CONCLUSION}

The potential for using selective and fully biodegradable compounds in the management of parasitic mites of honey bees is encouraging. Our results indicate that the expression of hsps in honey bees (except for hsp 40) could serve as biomarkers for assessing the health status of honey beesexposed either to Varroa infestation or to monoterpenoids used to treat this infestation. Further research is required to verify our results and to determine the molecular mechanism of honey bee tolerance to external stressors like botanical toxins and infestation with mites.

ACKNOWLEDGEMENTS. The authors would like to thank local beekeepers and science officers for collecting the honey bees and assisting during this project. We greatly appreciate E.H. Hong for analyzing the data.

DECLARATION OF INTEREST. The authors report no conflicts of interest.

\section{REFERENCES}

Ariana A., Ebadi R. \& TAhmasbi G.H. 2002: Laboratory evaluation of some plant essences to control Varroa destructor (Acari: Varroidae). - Exp. Appl. Acarol. 27: 319-327.

Boncristiani H., Underwood R., Schwarz R., Evans J.D., Pettis J. \& VAN ENGELSDORP D. 2012: Direct effect of acaricides on pathogen loads and gene expression levels of honey bee Apis mellifera. - J. Insect Physiol. 58: 613-620.

Burt S.A., van der Zee R., Koets A.P., de Graaff A.M., van Knapen F., Gaastra W., Haagsman H.P. \& Veldhuizen E.J.A. 2007: Carvacrol induces heat shock protein 60 and inhibits synthesis of flagellin in Escherichia coli O157:H7. — Appl. Environ. Microbiol. 73: 4484-4490.

Carayon J.L., Téné N., Bonnafé E., Alayrangues J., Hotier L., Armengaud C. \& Treillou M. 2013: Thymol as an alternative to pesticides: Persistence and effects of Apilife Var on the phototactic behavior of the honey bee Apis mellifera. - Environ. Sci. Pollut. Res. 21: 4934-4939.

Carmel J., Rashrovetsky E., Nevo E. \& Korol A. 2011: Differential expression of small heat shock protein genes Hsp23 and Hsp40, and heat shock gene Hsr-omega in fruit flies (Drosophila melanogaster) along a microclimatic gradient. $-J$. Hered. 102: 593-603.

CoLIN M.E. 1990: Essential oils of Labiatae for controlling honey bee varroosis. - J. Appl. Entomol. 110: 19-25.

Cui Y.D., Du Y.Z., Lu M.X. \& Qiang C.K. 2010: Cloning of the heat shock protein 60 gene from the stem borer, Chilo suppressalis, and analysis of expression characteristics under heat stress. - J. Insect Sci. 10: 100, 13 pp.

Dai P.L., WANG Q., Sun J.H., Liu F., Wang X., Wu Y.Y. \& Zhou T. 2010: Effects of sublethal concentrations of bifenthrin and deltamethrin on fecundity, growth, and development of the honey bee Apis mellifera ligustica. - Environ. Toxicol. Chem. 29: 644-649.

Doganlar O. \& Doganlar Z.B. 2015: Responses of antioxidant enzymes and heat shock proteins in Drosophila melanogaster to treatment with a pesticide mixture. - Arch. Biol. Sci. (Belgrade) 67: 869-876.

Du Rand E.E., Smit S., Beukes M., Apostolides Z., Pirk C.W.W. \& Nicolson S.W. 2015: Detoxification mechanisms of honey bees (Apis mellifera) resulting in tolerance of dietary nicotine. - Sci. Rep. 5: 11779, 11 pp.

Elsik C.G., Worley K.C., Bennett A.K., Beye M., Camara F., Childers C.P., de Graaf D.C., Debyyser G., Deng J., Devreese B. ET AL. 2014: Finding the missing honey bee genes: lessons learned from a genome upgrade. - BMC Genomics 15: 14712164.

Feder M.E. \& Hofmann G.E. 1999: Heat-shock proteins, molecular chaperones, and the stress response: Evolutionary and ecological physiology. - Annu. Rev. Physiol. 61: 243-282.

Gong L., Chen X., Liu C., Jin F. \& Hu Q. 2014: Gene expression profile of Bombyx mori hemocyte under the stress of destruxin A. - PLoS ONE 9(5): e96170, 9 pp.

Gonzalez-Coloma A., Reina M., Diaz C.E. \& Fraga B.M. 2010: Natural product-based biopesticides for insect control. In Mander L. \& Liu H.-W. (eds): Comprehensive Natural Products II. Chemistry and Biology. Vol. 3: Development and Modification of Bioactivity. Elsevier, Amsterdam, pp. 237-268.

GREATTI M. \& BARBATININ R. 1996: Efficacy of a product containing sulphur, garlic, and pepper against Varroa jacobsoni and its tolerance by Apis mellifera. - Selez. Vet. 1: 9-20.

Gregorc A. \& Ellis J.D. 2011: Cell death localization in situ in laboratory reared honey bee (Apis mellifera L.) larvae treated with pesticides. - Pestic. Biochem. Physiol. 99: 200-207.

Huang L.H., Wang C.Z. \& Kang L. 2009: Cloning and expression of five heat shock protein genes in relation to cold hardening and development in the leaf miner, Liriomyza sativa. $-J$. Insect Physiol. 55: 279-285.

HummelbrunNer L. \& IsMan M.B. 2001: Acute, sublethal, antifeedant, and synergistic effects of monoterpenoid essential oil compounds on the tobacco cutworm, Spodoptera litura (Lep., Noctuidae). - J. Agric. Food Chem. 49: 715-720.

Imdorf A., Baogdanov S., OAchoa R.I. \& CaLderone N.W. 1999: Use of essential oils for the control of Varroa jacobsoni Oud. in honey bee colonies. - Apidologie 30: 209-228.

Isman M.B. 2006: Botanical insecticides, deterrents and repellents in modern agriculture and an increasingly regulated world. - Annu. Rev. Entomol. 51: 45-66.

Jiang X., Zhai H., Wang L., Luo L., Sappington T.W. \& Zhang L. 2012: Cloning of the heat shock protein 90 and 70 genes from the beet armyworm, Spodoptera exigua, and expression characteristics in relation to thermal stress and development. - Cell Stress Chaper. 17: 67-80.

Johnson R.M., Ellis M.D., Mullin C.A. \& Frazier M. 2010: Pesticides and honey bee toxicity - USA. - Apidologie 41: 312-331.

KING A.M. \& MACRAE T.H. 2015: Insect heat shock proteins during stress and diapause. - Annu. Rev. Entomol. 60: 59-75.

Koo J., Son T.G., Kim S.Y. \& LeE K.Y. 2015: Differential responses of Apis mellifera heat shock protein genes to heat shock, flower-thinning formulations, and imidacloprid. - J. Asia Pac. Entomol. 18: 583-589.

Li J., Moghaddam H.H., Du X., Zhong B. \& Chen Y.Y. 2012: Comparative analysis on the expression of inducible HSPs in the silkworm, Bombyx mori. - Mol. Biol. Rep. 39: 3915-3923.

Li L., Lin Z.-G., Wang S., Su X.-L., Gong H.-R., Li H.-L., Hu F.-L. \& ZHENG H.-Q. 2017: The effects of clove oil on the en- 
zyme activity of Varroa destructor Anderson and Trueman (Arachnida: Acari: Varroidae). — Saudi J. Biol. Sci. [in press] DOI: $10.1016 /$ j.sjbs.2017.01.052

LivaK K.J. \& SchmitTGEN T.D. 2001: Analysis of relative gene expression data using real time quantitative PCR and the $2^{-\Delta \Delta} \mathrm{Ct}$ method. - Methods 25: 402-408.

LOCKE B. 2015: Natural Varroa mite-surviving Apis mellifera honey bee populations. - Apidologie 47: 467-482.

Lourenco A.P., Mackert A., Cristino A.D.S. \& Simoes Z.L.P. 2008: Validation of reference genes for gene expression studies in the honey bee, Apis mellifera, by quantitative real-time RTPCR. - Apidologie 39: 372-385.

Lu C., Warchol K. \& Callahan R.A. 2014: Sub-lethal exposure to neonicotinoids impaired honey bees winterization before proceeding to colony collapse disorder. - Bull. Insectol. 67: $125-130$.

Mahroof R., Yan Zhu K., Neven L., Subramanyam B. \& Bai J. 2005: Expression patterns of three heat shock protein 70 genes among developmental stages of the red flour beetle, Tribolium castaneum (Coleoptera: Tenebrionidae). - Comp. Biochem. Physiol. 141: 247-256.

Melathopoulos A.P. \& Gates J. 2003: Comparison of two thymol-based acaricides, Api LifeVar (R) and Apiguard TM, for the control of varroa mites. - Am. Bee J. 43: 489-493.

OldRoYd B.P. 2007: What's killing American honey bees? PLoS Biol. 5: 1195-1199.

Parnas M., Peters M., Dadon D., Lev S., Vertkin I., Slutsky I. \& Minke B. 2009: Carvacrol is a novel inhibitor of Drosophila TRPL and mammalian TRPM7 channels. - Cell Calcium 45: 300-309.

QAYYOUM M.A., Khan B.S. \& BASHIR M.H. 2013: Efficacy of plant extracts against honey bee mite, Varroa destructor (Acari: Varroidae). - World J. Zool. 8: 212-216.

Qiao L., Wu J.X., QIN D.Z., Liu X.C., Lu Z.C., Lv L.Z., Pan Z.L., Chen H. \& Li G.W. 2015: Gene expression profiles of heat shock proteins 70 and 90 from Empoasca onukii (Hemiptera: Cicadellidae) in response to temperature stress. - J. Insect Sci. 15(1): 49, 12 pp.

Rinehart J.P., Denlinger D.L. \& Rivers D.B. 2002: Upregulation of transcripts encoding select heat shock proteins in the flesh fly Sarcophaga crassipalpis in response to venom from the ectoparasitoid wasp Nasonia vitripennis. - J. Invertebr. Pathol. 79: 62-63.

Ritossa F. 1962: A new puffing pattern induced by temperature shock and DNP in Drosophila. - Experientia 18: 571-574.

Sahayaraj K. 2014: Basic and Applied Aspects of Biopesticides. Springer India, $384 \mathrm{pp}$.

Shakya B., Jyoti S., Naz F., Khan S., Afzal R.M. \& Siddique Y.H. 2012: Effect of L-ascorbic acid on the hsp70 expression and tissue damage in the third instar larvae of transgenic Drosophila melanogaster (hsp70-lacZ) Bg (9). - Toxicol. Int. 19: 301-305.

Shim J.K., Ha D.M., Nho S.K., Song K.S. \& LeE K.Y. 2007: Upregulation of heat shock protein genes by envenomation of ectoparasitoid Bracon hebetor in larval host of Indian meal moth Plodia interpunctella. - J. Invertebr. Pathol. 97: 306-309.

SinGH D. 2014: Management of mite pests in honey bee colonies through botanicals. In Singh D. (ed.): Advances in Plant Biopesticides. Springer India, pp. 271-277.

SMOdis Skerl M.I. \& Gregorc A. 2010: Heat shock proteins and cell death in situ localisation in hypopharyngeal glands of honey bee (Apis mellifera carnica) workers after imidacloprid or coumaphos treatment. - Apidologie 41: 73-86.
Stephanou A. \& Latchman D.S. 2011: Transcriptional modulation of heat-shock protein gene expression. - Biochem. Res. Int. 2011: 238601, 8 pp.

Sun Y., Sheng Y., Bai L., Zhang Y., XiaO Y., Xiao L., Tan Y. \& SHeN Y. 2014: Characterizing heat shock protein 90 gene of Apolygus lucorum (Meyer-Dur) and its expression in response to different temperature and pesticide stresses. - Cell Stress Chaper. 19: 725-739.

Szabo A., Korszun R., Hartl F.U. \& Flanagan J. 1996: A zinc finger-like domain of the molecular chaperone DnaJ is involved in binding to denatured protein substrates. - EMBO J. 15: 408-417.

Tachibana S.I., Numata H. \& Goto S.G. 2005: Gene expression of heat shock proteins (Hsp23, Hsp70 and Hsp90) during and after larval diapause in the blow fly Lucilia sericata. - J. Insect Physiol. 51: 641-647.

Tissieres A., Mitchell H.K. \& Tracy U.M. 1974: Protein synthesis in salivary glands of Drosophila melanogaster: Relation to chromosome puffs. - J. Mol. Biol. 85: 389-398.

Tunguttwitayakul J., Tatun N., Vajarasathir B. \& Sakurai S. 2015: Expression of heat shock protein genes in different developmental stages and after temperature stress in the maize weevil (Coleoptera: Curculionidae). - J. Econ. Entomol. 108: 1313-1323.

Umpiérrez M.L., Santos E., Gonźalez A. \& Rossini C. 2011: Plant essential oils as potential control agents of varroatosis. - Phytochem. Rev. 10: 227-244.

Van Engelsdorp D., Evans J.D., Saegerman C., Mullin C., Haubruge E., Nguyen B.K., Frazier M., Frazier J., Cox-Foster D., Chen Y., Underwood R., Tarpy D.R. \& Pettis J.S. 2009: Colony collapse disorder: a descriptive study. - PLoS ONE 4: e6481, $17 \mathrm{pp}$.

Wang H.-H., Reitz S.R., Wang L.-X., Wang S.-Y, Li X. \& LeI Z.-R. 2014: The mRNA expression profiles of five heat shock protein genes from Frankliniella occidentalis at different stages and their responses to temperatures and insecticides. $-J$. Integr. Agric. 13: 2196-2210.

WANG L., YANG S., ZhaO K. \& LANLAN H. 2015: Expression profiles of the heat shock protein 70 gene in response to heat stress in Agrotis c-nigrum (Lepidoptera: Noctuidae). - J. Insect Sci. 15(9): 2015, 6 pp.

Xavier V.M., Message D., Picanco M.C., Chediak M., Santana JunioR P.A., Ramos R.S. \& Martins J.C. 2015: Acute toxicity and sublethal effects of botanical insecticides to honey bees. J. Insect Sci. 15(1): 137, 6 pp.

YANG F.L., Li X.G., Zhu F. \& Lei C.L. 2009: Structural characterization of nanoparticles loaded with garlic essential oil and their insecticidal activity against Tribolium castaneum (Herbst) (Coleoptera: Tenebrionidae). - J. Agric. Food Chem. 57: 10156-10162.

Yuan X., Zhou W.W., Zhou Y., Liu S., Lu F., Yang M.F., Cheng J., GURR G.M. \& ZHU Z.R. 2014: Composition and expression of heat shock proteins in an invasive pest, the rice water weevil (Coleoptera: Curculionidae). - Fla Entomol. 97: 611-619.

Zaluski R., Kadri S.M., Alonso D.P., Ribolla M.P.E. \& Orsi R.D.O. 2015: Fipronil promotes motor and behavioural changes in honey bees (Apis mellifera) and affects the development of colonies exposed to sublethal doses. - Environ. Toxicol. Chem. 34: 1062-1069.

Zhang Q. \& Denlinger D.L. 2010: Molecular characterization of heat shock protein 90,70 and 70 cognate cDNAs and their expression patterns during thermal stress and pupal diapause in the corn earworm. - J. Insect Physiol. 56: 138-150.

Zhang L.J., Wang K.F., JiNG Y.P., ZhuANG H.M. \& Wu G. 2015: Identification of heat shock protein genes $h s p 70 \mathrm{~s}$ and $h s c 70$ 
and their associated mRNA expression under heat stress in insecticide-resistant and susceptible diamondback moth, Plutella xylostella (Lepidoptera: Plutellidae). — Eur. J. Entomol. 112 215-226.

ZhAo L. \& Jones W.A. 2012: Expression of heat shock protein genes in insect stress responses. - Invertebr. Surviv. J. 9: 93-101.
Zhu J.Y., Wu G.X., Ye G.Y. \& Hu C. 2013: Heat shock protein genes (hsp20, hsp75 and hsp90) from Pieris rapae: Molecular cloning and transcription in response to parasitization by Pteromalus puparum. - Insect Sci. 20: 183-193.

Received August 6, 2016; revised and accepted March 14, 2017 Published online April 7, 2017 